\title{
First year reflections: Basic guidelines and future directions
}

\author{
Pep Simo, Mihaela Enache, Jose M. Sallan, Vicenc Fernandez \\ Universitat Politècnica de Catalunya (Spain) \\ pep.simo@,upc.edu; mibaela.enache@upc.edu; jose.maria.sallan@,upc.edu; vicenc.fernandez@upc.edu
}

\begin{abstract}
This issue opens the second volume of the Journal of Industrial Engineering and Management, and with this issue begins our second year of publication. The aim of this editorial is to evaluate the 2008 activities, by presenting the members of the Editorial Board and the reviewers of the journal, as well as by reflecting results of quality, prestige and visibility of the journal, which are derived from the perception of the authors, who have sent us their work. Finally, the main conclusions are drawn and future lines of research for the second volume are presented.
\end{abstract}

Keywords: JIEM, editorial, future directions, authors' satisfaction

\section{Introduction}

One year after publishing the first editorial (Fernandez et al., 2008), we started the second volume presenting to all the stakeholders of the journal our particular vision regarding the journal's evolution during the first year. In addition, guidelines and goals for this new volume are provided, with the aim of emphasizing the social responsibility of this open-access scientific publication, like other journals (e.g., Simo \& Sallan, 2008) of maximum transparency to the professional and academic community.

The new open-access journals include four basic axes (Simo et al., 2006) that are essential in the early years and should be stimulated and constantly improved by their editorial policy: quality, prestige, social responsibility and economic viability. In fact, these aspects are the basic guidelines that we followed during the first volume and they will be further detailed in the following sections. 
In order to assess some of the above mentioned aspects, we have relied on the journal's own data (i.e., review times, number of manuscripts received, number of accepted manuscripts), the composition of the editorial board, the board of reviewers, and a satisfaction survey conducted with the authors who have submitted an article for review during 2008.

\section{I nitial balance}

The first volume of the journal included two issues with total of twelve articles and an editorial. Given that the first issue simply opened the journal with a call for papers, we consider that balance of the first year is satisfactory, compared with other similar open access journals. After the call for papers, during 2008 we received 38 manuscripts, out of which 23 were accepted $(60.5 \%), 10(26.3 \%)$ rejected and five remain still under review (13.2\%). Out of these 23 papers accepted, 13 (56.5\%) were published in 2008 and the rest will be published during 2009. Thus, the average review time is 50 days and the average publishing time 86 days, respectively. However, these figures may slightly vary depending on the last remaining papers received in 2008. The data are available in real time by accessing the following link: http://jiem.org/index.php/jiem/about/statistics?statisticsYear=2008. A total of 29 authors from six different countries have published in JIEM during 2008 and 189 users (among which readers, authors and reviewers) registered with the journal.

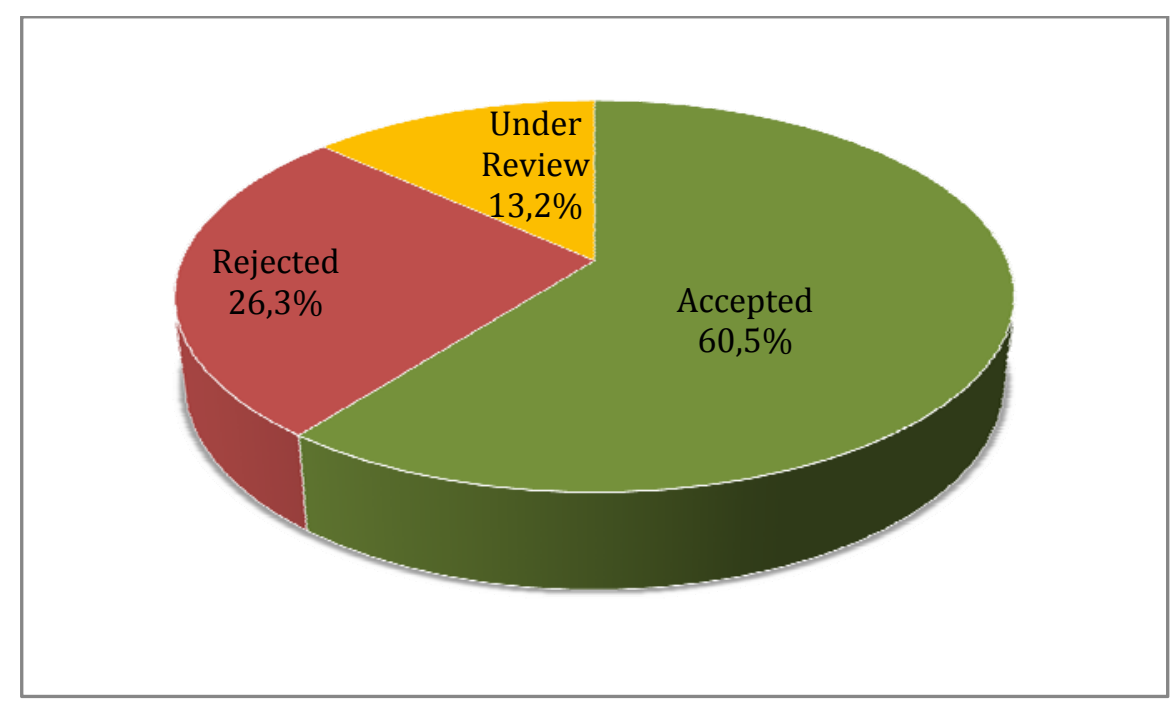

Figure 1. "Papers received during 2008" 


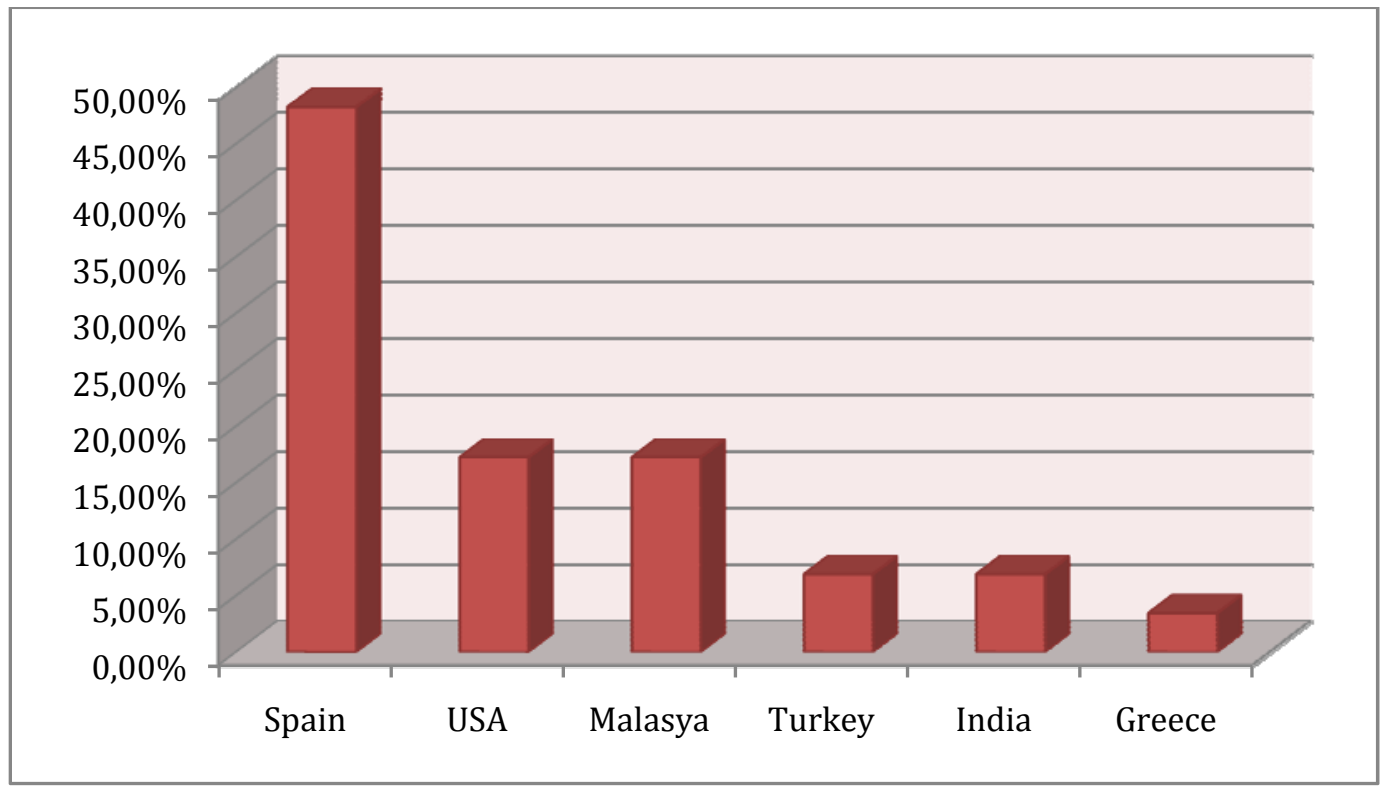

Figure 2. "Nationalities of the authors who published in JIEM during 2008"

In order assess the satisfaction of the authors who have submitted a paper to JIEM during 2008, a questionnaire, which examines different dimensions that will be explained in the next sections, was designed. The survey, which was totally voluntary and anonymous, was sent to the 101 authors of the 38 articles received in 2008 . The response rate was of $26.7 \%$. $88.4 \%$ of the authors who completed the survey had the paper accepted for publication. The average age of respondents was 39.02 years $(S D=9.96)$ and the $23.07 \%$ of them were women. With regard to their educational background, $61.53 \%$ held $\mathrm{a} \mathrm{PhD}$ and the rest of them were PhD students. The respondents represented a diverse set of countries: Spain (46.15\%), Malaysia (15.38\%), USA (11.54\%), India (11.54\%), Iran $(3.85 \%)$, Turkey (3.85\%), Taiwan (3.85\%) and Canada (3.85\%). $92.30 \%$ of them worked in a Public University, and the rest of them, in other institutions. The questionnaire was conducted using a Likert scale of five points.

\section{Quality}

Without forgetting the responsibility of the editors, we would like thank to thank the Editorial Board and the team of reviewers, who have voluntarily contributed to the quality of the journal. Despite of being made public (http://www.jiem.org/index.php/jiem/about/editorialTeam), the Editorial Board might have 
modified throughout the year, and hence, we believe it is important to reflect all its members

Production, Logistics, Quality, and Operational Research

\begin{tabular}{l|l} 
Ramon Companys & UniversitatPolitècnica de Catalunya
\end{tabular}

Albert CorominasSubias UniversitatPolitècnica de Catalunya

EulaliaGrifulPonsati UniversitatPolitècnica de Catalunya

Ki-Young Jeong

Luis López

AmaiaLusa University of Houston-Clear Lake

INCAE

Cecilio Mar Molinero UniversitatPolitècnica de Catalunya University of Kent - Kent Business School

MonserratPepióViñals UniversitatPolitècnica de Catalunya

Spain

Spain

Spain

USA

Costa Rica

Spain

United Kingdom

I nformation Systems, Technology and Communication

J osepCollBertran

Janni Nielsen

J oan RodónMòdol

J ose L. Salmerón

UniversitatPolitècnica de Catalunya

Copenhagen Business School

ESADE

University Pablo de Olavide

Spain

Industrial Economics and Regional Development

\begin{tabular}{|l|l|l|}
\hline $\begin{array}{l}\text { Manuel Antonio } \\
\text { EspitiaEscuer }\end{array}$ & Universidad de Zaragoza & Spain \\
\hline Henry Etzkowitz & Newcastle University & United Kingdom \\
\hline Carlos Rodriguez Monroy & Madrid Technological University (UPM) & Spain \\
\hline FrancescSoléParellada & UniversitatPolitècnica de Catalunya & Spain \\
\hline
\end{tabular}

Management, Organizational Behaviour and Human Resources

\begin{tabular}{|l|l|}
\hline Marc Bonnet & ISEOR - University Jean Moulin Lyon 3
\end{tabular}

Constantin Bratianu

Francisco J avier Carrillo

Ramon Cladellas

Academy of Economic Studies

Tecnológico de Monterrey

Spain

Denmark

Spain

Spain

Ercilia Garcia-Alvarez

Pablo Martin de Holan

J oan Mundet Hiern

Nelson Phillips

Lidia Puigvert

Henri Savall

Ramon Valle Cabrera

Véronique Zardet

Universitat Autònoma de Barcelona

Universitat Rovira i Virgili

Instituto de Empresa (IE)

Universitat Politècnica de Catalunya

(UPC)

Imperial College London

Universitat de Barcelona

France

Romania

Mexico

Spain

Spain

Spain

Spain

ISEOR - Université Jean Moulin Lyon 3

Universidad Pablo de Olavide

United Kingdom

Spain

SEOR - Université J ean Moulin Lyon 3 France

Finance, Accounting and Marketing in Industrial Sectors

Jose Antonio Almaça $\quad$ Universidade Autónoma de Lisboa

Valentín Azofra Palenzuela

David Castillo

Universidad de Valladolid

Universitat Oberta de Catalunya

(UOC)

Francisco Martin Peña

Carme Martinez

Universitat de Barcelona

Universitat Politècnica de Catalunya

(UPC)

Lourdes Perez

J osep Maria Rosanas

EADA International Management

IESE Business School

J oan R. Tarradellas

EADA Business School / UPC

Portugal

Spain

Spain

Spain

Spain

Spain

Spain

Spain 


\section{Education, Training and Professional Skills}

\begin{tabular}{|l|l|l|}
\hline Francisco Aliaga Abad & Universidad de Valencia & Spain \\
\hline Juan A. Marin-Garcia & Universidad Politécnica de Valencia & Spain \\
\hline Rafael Pindado Rico & $\begin{array}{l}\text { Universitat Politècnica de Catalunya } \\
\text { (UPC) }\end{array}$ & Spain \\
\hline Cristina Poyatos Matas & Griffith University & Australia \\
\hline
\end{tabular}

Table 1. "Members of the editorial board during 2008"

\begin{tabular}{|c|c|c|}
\hline Name & Afiliation & Country \\
\hline Valentín Azofra Palenzuela & Universidad de Valladolid & Spain \\
\hline Marc Bonnet & $\begin{array}{l}\text { ISEOR - University J ean Moulin (Lyon } \\
\text { 3) }\end{array}$ & France \\
\hline Ramon Cladellas & Universitat Autònoma de Barcelona & Spain \\
\hline Ramon Companys & Universitat Politècnica de Catalunya & Spain \\
\hline Albert Corominas Subias & Universitat Politècnica de Catalunya & Spain \\
\hline Gholam Reza Esmaeilian & Universiti Putra & Malaysia \\
\hline Marta Fernández-Olmos & University of Zaragoza & Spain \\
\hline SorabhGupta & $\begin{array}{l}\text { Haryana College of Technology and } \\
\text { Management }\end{array}$ & India \\
\hline Frederic GarrigaGarzón & Universitat Politècnica de Catalunya & Spain \\
\hline Azman Ismail & Universiti Malaysia Sarawak & Malaysia \\
\hline Ki-Young J eong & University of Houston-Clear Lake & USA \\
\hline Anastasia A. Katou & University of Macedonia & Greece \\
\hline Rajiv khanduja & S.k.i.e.t. Kurukshetra University & India \\
\hline Carl J oachim Kock & Instituto de Empresa & Spain \\
\hline L. Siva Rama Krishna & Osmania University & India \\
\hline Carmen Llinares & Universidad Politécnica de Valencia & Spain \\
\hline Luis López & INCAE & Costa Rica \\
\hline Juan A. Marin-Garcia & Universidad Politécnica de Valencia & Spain \\
\hline Pablo Martin de Holan & Instituto de Empresa (IE) & Spain \\
\hline Francisco Martin Peña & Universitat de Barcelona & Spain \\
\hline Carme Martinez & Universitat Politècnica de Catalunya & Spain \\
\hline Lukasz Maciej Mazur & North Carolina State University & USA \\
\hline Herwig Mittermayer & Universidad Politécnica de Madrid & Spain \\
\hline Josefina Lucia Murillo-Luna & University of Zaragoza & Spain \\
\hline Lourdes Perez & EADA International Management & Spain \\
\hline Rafael Pindado Rico & Universitat Politècnica de Catalunya & Spain \\
\hline Cristina Poyatos Matas & Griffith University & Australia \\
\hline Juan Carlos Ramón-Solans & University of Zaragoza & Spain \\
\hline Joan Rodón Mòdol & ESADE & Spain \\
\hline Carlos Rodriguez Monroy & Madrid Technological University (UPM) & Spain \\
\hline Imma Ribas Vila & Universitat Politècnica de Catalunya & Spain \\
\hline Albert Suñé Torrents & UniversitatPolitènica de Catalunya & Spain \\
\hline Joan TarradellasiEspuny & EADA Business School / UPC & Spain \\
\hline Ramon Valle Cabrera & Universidad Pablo de Olavide & Spain \\
\hline José Ramón Vilana & Bystronic & Spain \\
\hline
\end{tabular}

Table 2. "Reviewers who have participated in at least one review during the 2008" 
With respect to the authors' perception of the different quality dimensions of the journal, the next table shows very satisfactory results, taking into account that the object of the survey was a journal in its first year of publication:

\begin{tabular}{|lcc|}
\hline \multicolumn{1}{|c|}{ ITEM } & M & SD \\
\hline The reviewers' feedback was adequate & 4.16 & 0.89 \\
\hline The editor's feedback was adequate & 4.39 & 0.82 \\
\hline $\begin{array}{l}\text { Overall, the comments and the responses received from the } \\
\text { journal were adequate }\end{array}$ & 4.19 & 0.86 \\
\hline $\begin{array}{l}\text { The information offered to the authors (e.g., editorial policy, } \\
\text { standards of publication, indexing) is clear and concise }\end{array}$ & 4.20 & 0.79 \\
\hline The journal has a fair and transparent editorial policy & 4.16 & 0.78 \\
\hline
\end{tabular}

Table 3. "Perception of the authors who have submitted an article in 2008 in relation to

$$
\text { quality" }
$$

\section{Prestige}

The prestige of the scientific publications is closely linked to the quality of the papers it publishes and it is the scientific community itself that judges it (Simo \& Sallan, 2008). On the other hand, as far as we are concerned, as editors, we must work so that the journals' prestige will be recognized and valued internationally. The main tool for achieving this aim is the journal indexation in different databases of scientific prestige. During this first year, the journal has been indexed/abstracted in seven databases, including Dialnet and DOAJ. Obviously, this is a continuous process, as most indexes require a minimum level of impact of the papers and a minimum of two years of existence of the journal.

Although, currently and given the youth of the journal, this is not indexed in the most prestigious databases, the prestige of the Editorial Board or of the institution, which supports it, balances the perception of the authors with regard to the prestige of the journal. Nevertheless, this is, undoubtedly, one of the aspects to which more effort should be devoted in the future, in order to consolidate this publication, taking into account that the time variable is very significant in this process. 


\begin{tabular}{|lcc|}
\hline \multicolumn{1}{|c}{ ITEM } & M & SD \\
\hline The editors of this journal are widely renowned in their academic field & 3.75 & 0.65 \\
\hline The Editorial Board members are recognized experts & 3.79 & 0.62 \\
\hline The entity that publishes the journal is widely renowned & 3.61 & 0.69 \\
\hline $\begin{array}{l}\text { The papers published in this journal have high visibility in the scientific } \\
\text { community of the area(s) it specializes in }\end{array}$ & 3.15 & 1.15 \\
\hline $\begin{array}{l}\text { Publications in this journal are recognized by the scientific community } \\
\text { related to the subject area }\end{array}$ & 3.35 & 0.83 \\
\hline $\begin{array}{l}\text { Publications in this journal are recognized by the organization for which I } \\
\text { work }\end{array}$ & 3.37 & 1.08 \\
\hline $\begin{array}{l}\text { This journal is included in relevant scientific databases and/or recognized } \\
\text { by those professionals, who are important to me }\end{array}$ & 2.97 & 1.28 \\
\hline $\begin{array}{l}\text { The papers published in this journal have is a high visibility beyond the } \\
\text { scientific community }\end{array}$ & 3.12 & 0.94 \\
\hline
\end{tabular}

Table 4. "Perception of the authors who have submitted an article in 2008 in relation to the prestige of the journal"

\section{International outreach}

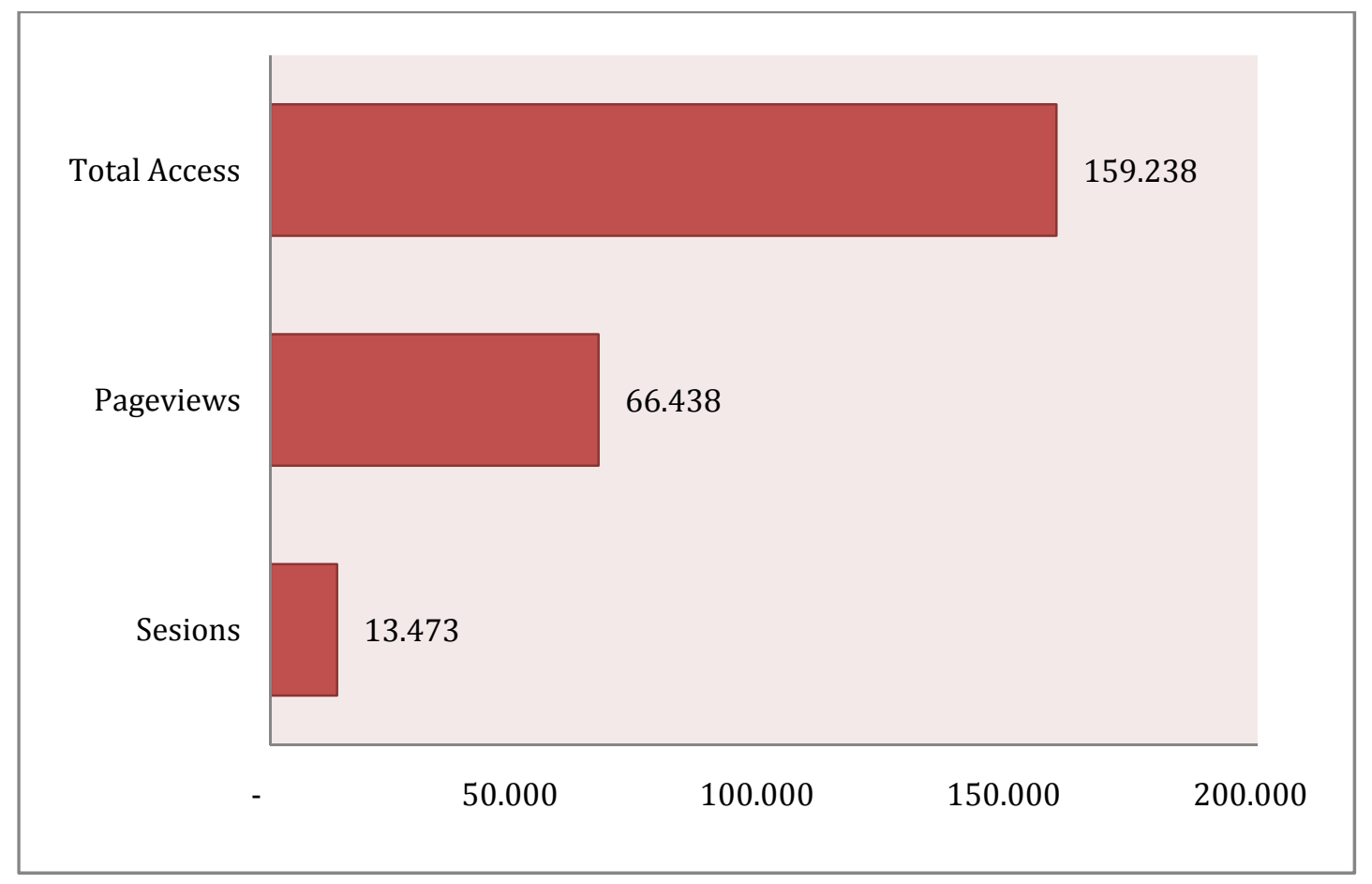

Figure 3. "Visibility of the journal in 2008" 
The social responsibility of a journal concerns, among other aspects, the entirely free and open dissemination of its contents, trying to cover the greatest diversity of academic and professional potential. In this regard, since its inception, we have worked to improve the web positioning of the journal and of its papers, reaching a Google PageRank of 6/10 and very acceptable levels of visibility, with a total of 1.37 GB transferred in 2008. This represents a daily average of 36.81 sessions, 181.52 pages seen and 435.08 pages accessed, in more than 90 countries.

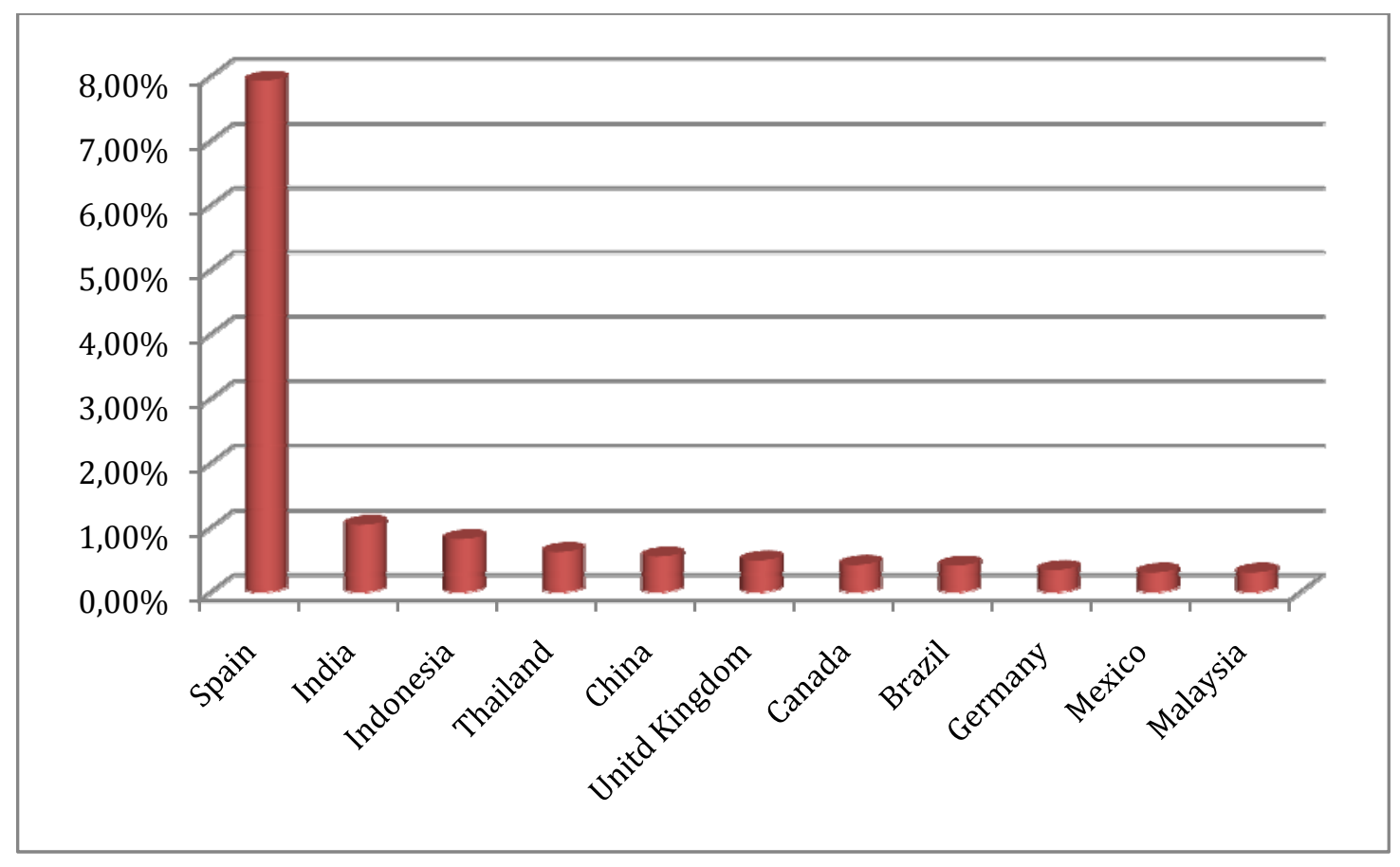

Figure 4. "Main countries of access to the journal in 2008"

\section{Conclusions and future directions}

The readers and the authors are the ones who should evaluate the first year of the journal, based on the papers published and the results presented in this editorial. We believe that we must continue working primarily for enhancing the prestige of the JIEM. As shown by the results of the survey above mentioned, further work is essential to include the journal into databases of scientific credibility and relevance for the various institutions where the authors work. Nevertheless, it is worth noting that this is a relatively slow and steady process in which targets must be set in the medium term. Apart from that, we expect for the next volume to significantly increase the number of databases in which the JIEM is indexed. 


\begin{tabular}{|lcc|}
\hline \multicolumn{1}{|c|}{ ITEM } & M & SD \\
\hline $\begin{array}{l}\text { If I had to start again the process of sending this paper, I would } \\
\text { send it to this journal }\end{array}$ & 4.60 & 0.57 \\
\hline $\begin{array}{l}\text { The next time I have a similar paper, I will send it to this journal } \\
\text { In the future, it is very likely that I will re-submit a paper to this } \\
\text { journal }\end{array}$ & 4.30 & 0.70 \\
\hline
\end{tabular}

Table 5. "Intention to re-submit a paper to JIEM"

In a similar direction, during the early months of 2009, we have begun to gradually increase the Editorial Board of the journal, trying to make it as international as possible. We are also determined to increase the number of women who form Editorial Board, so that it would be comparable with the number of men, in each area. As a final note, it should be emphasized that the authors' satisfaction survey reveals that their intention to re-submit is very high, thus we can consider that we are walking in a good direction. That is, despite of being a young journal, we should not forget to genuinely thank the authors the trust they placed in the JIEM.

\section{References}

Fernandez, V., Simo, P., Sallan, J. M., \& Enache, M. (2008). JIEM: A new exciting journey into the research of industrial engineering and management. Journal of Industrial Engineering and Management, 1(1), 1-3.

Simo, P., Garcia-Parra, M., Sunyer, S.; Trullas, G., \& J orda, J. M. (2006). From the Editors: An assessment of open access journals: quality, prestige and social responsibility. Intangible Capital, 2(1), 1-20.

Simo, P., \& Sallan, J. M. (2008). Intangible Capital: Four years of growth as an open-access scientific publication. Intangible Capital, 4(1), 1-7.

(ㄷ) Journal of Industrial Engineering and Management, 2009 (www.jiem.org)

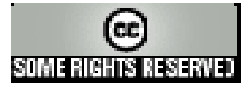

Article's contents are provided on a Attribution-Non Commercial 3.0 Creative commons license. Readers are allowed to copy, distribute and communicate article's contents, provided the author's and Journal of Industrial Engineering and Management's names are included. It must not be used for commercial purposes. To see the complete license contents, please visit http://creativecommons.org/licenses/by-nc/3.0/. 